\title{
Asfalteny naftowe - przegląd wybranych zagadnień
}

\begin{abstract}
Asfalteny naftowe są to polarne, aromatyczne składniki ropy naftowej o dużych masach cząsteczkowych. W trakcie przerobu ropy gromadzą się w znacznych ilościach w ciężkich frakcjach pozostałościowych. Ich obecność powoduje takie problemy jak zatykanie rurociągów oraz dezaktywację katalizatorów procesów pogłębionej konwersji. Jest to efektem skłonności asfaltenów do agregacji, skutkującej wytrącaniem osadów. W artykule opisano budowę cząsteczek asfaltenów, mechanizmy agregacji (flokulacji) i czynniki na nią wpływające, a także następstwa tego zjawiska. Przedstawiono również metody oceny stabilności fazowej ropy i produktów naftowych oraz omówiono działanie dodatków dyspergujących, służących jej poprawie.
\end{abstract}

Słowa kluczowe: asfalteny, ropa naftowa, agregacja, stabilność fazowa, dyspergatory.

\section{Petroleum asphaltenes - review of selected issues}

Asphaltenes are polar, aromatic and heavy-molecular-weight components of petroleum. During the processing of oil they accumulate in large quantities in heavy residue fractions. Their presence causes problems such as clogging of pipelines and deactivation of catalysts in deep conversion processes. This is due to the tendency of asphaltenes to aggregate resulting in precipitation. The article describes the structure of asphaltenes, the mechanisms of aggregation (flocculation) and the factors influencing it, as well as the consequences of this phenomenon. The methods of assessing the phase stability of crude oil and petroleum products are also presented, and the effects of dispersant additives are discussed.

Key words: asphaltenes, crude oil, aggregation, phase stability, dispersants.

\section{Wprowadzenie}

Ropa naftowa to niezmiennie najważniejsze źródło surowców do celów energetycznych oraz do syntez petrochemicznych. Różnorodność jej gatunków znacząco utrudnia opis budowy chemicznej. Skład węglowodorowy ropy określony jest przez zawartość składników grupowych, do których należą: węglowodory nasycone, węglowodory aromatyczne, żywice oraz asfalteny [1]. Węglowodory aromatyczne, nasycone oraz żywice stanowią fazę maltenową.

Polarne asfalteny są zdyspergowane w ropie naftowej przez żywice, tworzące wokół nich otoczkę stabilizującą. Micele żywiczno-asfaltenowe utrzymują się w postaci rozpuszczonej dzięki małocząsteczkowym związkom aromatycznym (rysunek 1) [31].

Podczas destylacji z ropy naftowej stopniowo usuwane są małocząsteczkowe węglowodory aromatyczne, stanowiące ośrodek dyspersyjny dla miceli żywiczno-asfaltenowych. Obniża się również zawartość węglowodorów nasyconych o krótkich i średniej długości łańcuchach. Obie te grupy charakteryzują się niską lepkością, zatem ich ubytek powoduje

\section{n a $\mathrm{n}$}

$\begin{array}{llllllll} & \mathrm{a} & \mathrm{n} & \mathrm{n} & \mathrm{a} & \mathrm{n} & \mathrm{n} & \mathrm{a}\end{array}$

n a $\dot{\mathbf{Z}} \dot{\mathbf{Z}} \dot{\mathbf{Z}} \mathrm{n}$ a

a $\mathrm{n} \dot{\mathrm{Z}} \mathbf{A} \mathbf{A} \dot{\mathbf{Z}}$ a $\mathrm{n}$

$\mathrm{n}$ a $\dot{\mathbf{Z}} \mathbf{A} \mathbf{A} \dot{\mathbf{Z}}$ a $\mathrm{n}$

a $n \dot{Z} \quad \dot{Z} \quad \dot{Z} n \quad a$

a $n \quad n \quad a \quad n \quad n \quad a$

a $\mathrm{n}$ a

Rys. 1. Model fizyczny ropy naftowej: A - asfalteny,

Ż - żywice, a - małocząsteczkowe węglowodory aromatyczne, $\mathrm{n}$ - węglowodory nasycone

znaczny wzrost tego parametru dla najwyżej wrzących frakcji. Zakłócona zostaje także równowaga dyspersji, a więc wytrącanie się osadów w ciężkich produktach naftowych o wysokiej lepkości jest problemem poważniejszym niż w przypadku ropy naftowej.

Obecność asfaltenów w ropie naftowej i frakcjach naftowych niekorzystnie wpływa na katalityczne procesy jej przerobu. Zmiany temperatury i ciśnienia, jak również zachodzące 
reakcje chemiczne przyczyniają się do zakłócenia równowagi dyspersji asfaltenowych, co skutkuje wytrącaniem się asfaltenów w postaci osadów. Dezaktywują one katalizatory oraz zatykają urządzenia procesowe, wymuszając zatrzymywanie instalacji. Wytrącanie asfaltenów powoduje problemy także podczas magazynowania i transportu ropy naftowej lub wysokowrzących produktów naftowych. $Z$ tego powodu asfalteny nazwano „cholesterolem ropy naftowej” [16].

Wypadające osady asfaltenowe narażają koncerny naftowe na straty z kilku powodów. Po pierwsze, zmniejszona przepustowość urządzeń przesyłających wymaga zwiększenia nakładów energetycznych w celu utrzymania zadanej szybkości pracy. Po drugie, cząsteczki usuwane jako osad są odpa- dem, a gdyby się nie wytrąciły, mogłyby zostać w jakiś sposób zagospodarowane w rafinerii (np. jako paliwo dla elektrociepłowni). Dodatkowo czyszczenie zbiorników, rurociągów i innych aparatów wiąże się z wyłączeniem ich z użytku, co samo w sobie przynosi straty.

Opisane niedogodności związane $\mathrm{z}$ asfaltenami skłaniają do wnikliwej analizy ich struktury i właściwości, ponieważ dokładniejsze poznanie budowy i właściwości asfaltenów może pomóc w opracowaniu sposobów zapobiegania wytrącaniu osadów asfaltenowych. W niniejszym artykule przedstawiono najważniejsze zagadnienia dotyczące tych składników ropy naftowej, zarówno z mikroskopowego, jak i makroskopowego punktu widzenia.

\section{Budowa asfaltenów}

Najszerzej stosowany sposób odróżnienia asfaltenów od innych składników grupowych opiera się na różnicach w rozpuszczalności. Asfalteny są nierozpuszczalne w alkanach, takich jak: n-pentan, n-heksan, n-heptan lub wyższych, ale rozpuszczalne w rozpuszczalnikach aromatycznych (np. benzen, toluen). Im mniej atomów węgla w łańcuchu alkanu, tym większa ilość wytrąconego osadu, ponieważ oprócz asfaltenów wytrącane są także żywice. Najpopularniejszym czynnikiem strącającym używanym w badaniach asfaltenów jest n-heptan, ponieważ nie powoduje on zmian w ich właściwościach [4].

Pod względem składu elementarnego asfalteny pochodzące z różnych światowych źródeł kopalin nie odbiegają znacząco od siebie. Oprócz węgla i wodoru cząsteczki asfaltenów zbudowane są także z heteroatomów, tj. azotu, tlenu i siarki, przy czym tej ostatniej jest zdecydowanie najwięcej. W asfaltenach skoncentrowana jest również większość pierwiastków śladowych, zwłaszcza niklu i wanadu.

Koncepcje dotyczące struktury asfaltenów na przestrzeni lat ulegały zmianom. Ich masę cząsteczkową początkowo szacowano w zakresie 1500-3000 atomowych jednostek masy. Proponowane struktury zawierały do 10 skondensowanych pierścieni, tworzących oligomery połączone mostkami siarkowymi i alkilowymi. Taka cząsteczka asfaltenu miała zawierać średnio od 40 do 70 pierścieni aromatycznych z heteroatomami [7]. Przykładowe modele asfaltenów zaproponowane w latach 80. i 90. XX wieku zaprezentowano na rysunku 2.

Nowsze dane uzyskane z badań nieniszczących, takich jak spektroskopia magnetycznego rezonansu jądrowego, elektronowego rezonansu paramagnetycznego oraz spektroskopia fourierowska w obszarze podczerwieni, wykazały, że średnią cząsteczkę asfaltenu można przedstawić jako pojedyncze zgrupowanie 5-7 skondensowanych pierścieni, połączonych łańcuchami alifatycznymi oraz mostkami z heteroatomami. Zmiany w strukturze asfaltenów ze wzrostem zawartości atomów
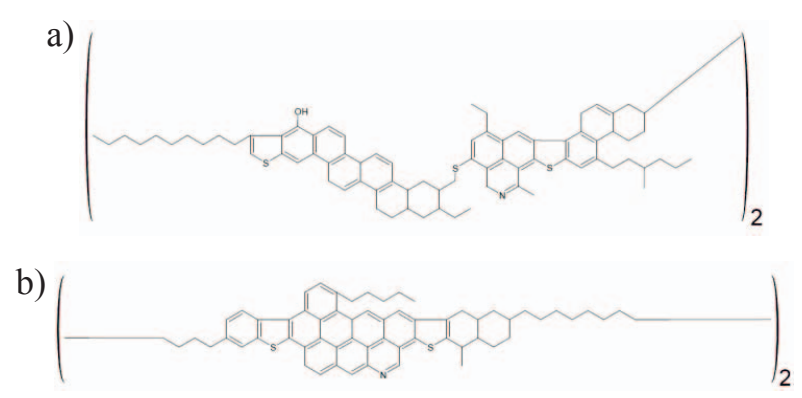

c)

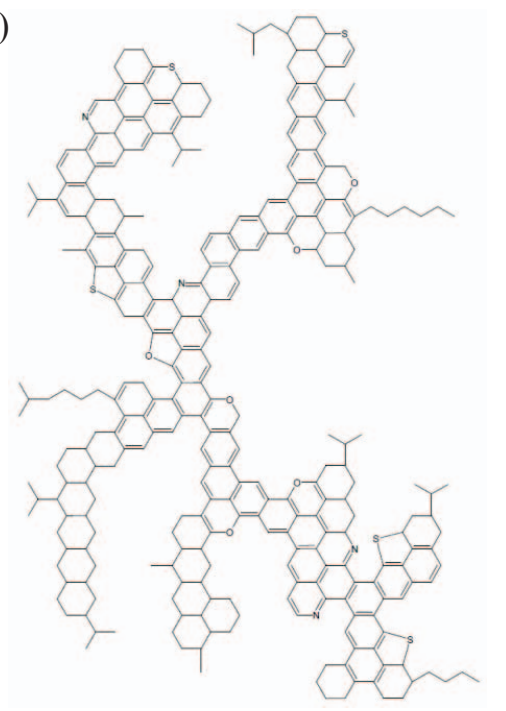

d)

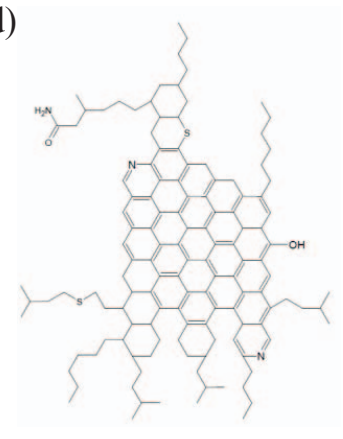

Rys. 2. Średnie modele cząsteczek asfaltenów z: a) piasków bitumicznych z Athabaski (Kanada) [27], b) ropy naftowej z Athabaski [27], c) ropy naftowej Maya (Meksyk) [3],

d) pozostałości 510C z ropy naftowej z Wenezueli [8]

węgla w cząsteczce można podsumować następująco: rośnie aromatyczność cząsteczki i średni rozmiar jej aromatycznego rdzenia, spada średnia długość węglowodorowych łańcuchów bocznych, zawartość heteroatomów oraz średnia masa cząsteczkowa [7].

Najnowsze techniki, takie jak spektroskopia depolaryzacji fluorescencyjnej, skłaniają się ku niższym wartościom mas 
Tablica 1. Masy cząsteczkowe i rozmiary cząsteczek asfaltenów według różnych źródeł

\begin{tabular}{|c|c|c|}
\hline Metoda & Masa cząsteczkowa i/lub rozmiar & Źródło \\
\hline Spektrometria mas z jonizacją pola & $800 \mathrm{u}$ & 6 \\
\hline $\begin{array}{l}\text { Spektrometria mas z analizatorem cyklotronowego rezonansu jonów } \\
\text { wytwarzanych electrosprayem z fourierowską transformacją wyników }\end{array}$ & 300-1400 u, w większości 400-800 u & 22 \\
\hline Spektrometria mas z jonizacją fotonową pod ciśnieniem atmosferycznym & 400-1200 u, głównie $750 \mathrm{u}$ & 20 \\
\hline Spektrometria mas z desorpcją/jonizacją pola & $\sim 1000 \mathrm{u}$, duży rozkład wartości & 26 \\
\hline Jonizacja $\mathrm{z}$ desorpcją laserową & $800-1000 \mathrm{u}$ & 15 \\
\hline Czasowo-rozdzielcza spektroskopia depolaryzacji fluorescencyjnej & $\begin{array}{l}500-1000 \text { u, głównie } 750 \mathrm{u} \text {, } \\
\text { odpowiadające średnicy } 2 \mathrm{~nm}\end{array}$ & 13 \\
\hline Dyfuzja w polu magnetycznego rezonansu jądrowego & $\begin{array}{l}\text { Średnica } 2 \mathrm{~nm} \text {, dimery } \\
\text { i pary cząsteczek większe }\end{array}$ & 21 \\
\hline Spektroskopia korelacji fluorescencji & $\sim 750$ u o średnicy $2,4 \mathrm{~nm}$ & 5 \\
\hline
\end{tabular}

cząsteczkowych (do 1000 u) i co się z tym wiąże - mniej skomplikowanym strukturom. Rozbieżność z wcześniejszymi szacunkami wynika z tego, że za pomocą niektórych metod (np. osmometrii ciśnieniowo-parowej) otrzymuje się masy agregatów, a nie pojedynczych cząsteczek asfaltenów [13]. Zestawienie różnych szacunków mas i/lub rozmiarów cząsteczek asfaltenów pokazano w tablicy 1 .

Różnorodność cząsteczek asfaltenów jest znaczna i wynika z obecności połączeń z siarką, azotem i tlenem, a także z innymi strukturami aromatycznymi. Biorąc pod uwagę zawartość węgla aromatycznego, stosunek grup metylenowych do metylowych, zawartość heteroatomów, typ i rozmiary struktur nasyconych oraz liczbę skondensowanych pierścieni aromatycznych, można wskazać kilka wyidealizowanych struktur asfaltenów [4]. Przykładowe struktury przedstawiono na rysunku 3.

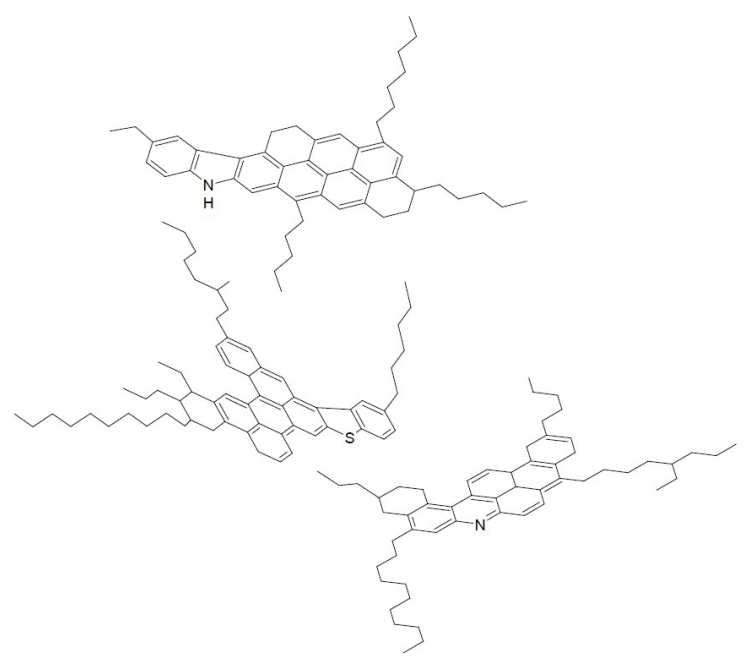

Rys. 3. Wyidealizowane struktury asfaltenów w ujęciu przestrzennym (na podstawie modeli Groenzina i Mullinsa [13])

Do przedstawienia przypuszczalnych struktur asfaltenów przydatne są symulacje molekularne tworzone na podstawie charakterystyki chemicznej cząsteczek. Można wyróżnić dwa odmienne modele: kontynentalny, według którego rdzenie cząsteczek są zbudowane $\mathrm{z}$ więcej niż siedmiu pierścieni aromatycznych, oraz archipelagowy, w którym mniejsze rdzenie aromatyczne są połączone łańcuchami węglowodorowymi [4]. Cząsteczkę asfaltenu typu kontynentalnego pokazano na rysunku 4, zaś typu archipelagowego na rysunku 5.

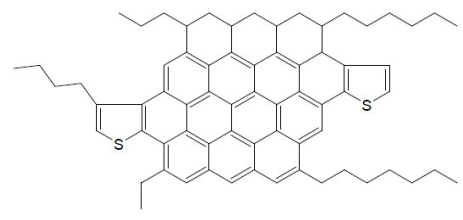

Rys. 4. Średnia struktura asfaltenu typu kontynentalnego z pozostałości z hydrokrakingu (na podstawie modeli Ancheyty i in. [4])

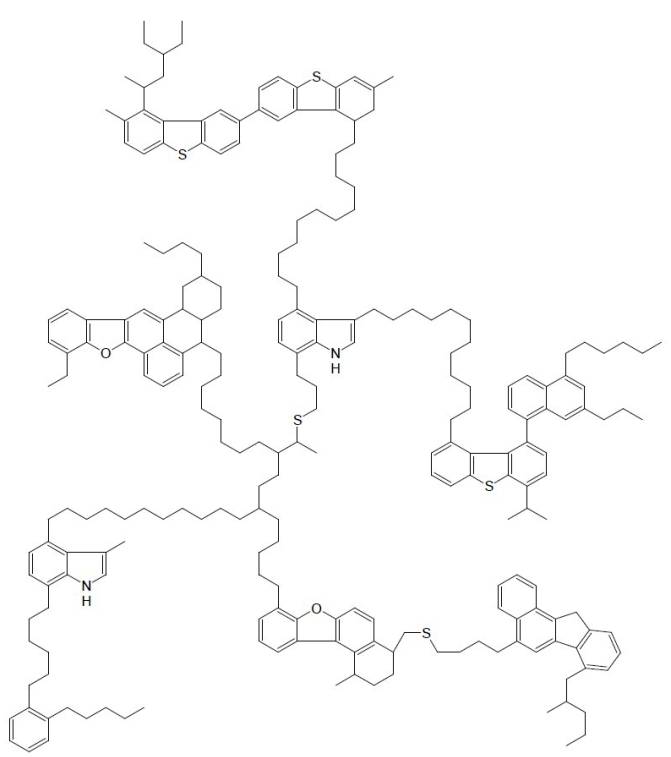

Rys. 5. Asfalteny typu archipelagowego (na podstawie modeli Ancheyty i in. [4]) 


\section{Agregacja asfaltenów i jej następstwa}

Zjawiskiem odpowiedzialnym za wszystkie niekorzystne aspekty obecności asfaltenów w ropie naftowej i produktach jej przerobu jest agregacja prowadząca do flokulacji i następnie wytrącania osadów asfaltenowych. Agregacja to łączenie się asfaltenów w coraz większe skupiska cząsteczek. Badania zachowania asfaltenów w rozpuszczalnikach aromatycznych (np. toluenie) wykazały, że agregacja zaczyna się przy stężeniu asfaltenów ok. 0,01\% mas. Poniżej tego stężenia asfalteny tworzą w toluenie roztwór rzeczywisty [1]. Wang i in. wykazali, że za agregację asfaltenów w rozpuszczalniku alifatycznym (konkretnie n-heptanie) odpowiadają wiązania van der Waalsa [29].

W ropie naftowej agregaty asfaltenów, otoczone warstwą zaadsorbowanych na nich żywic, tworzą micele odwrócone (ang. reverse micelles), tzn. ich część polarna znajduje się wewnątrz, a niepolarna skierowana jest do zewnątrz [14]. W przypadku asfaltenów częścią polarną są rdzenie aromatyczne złożone ze skondensowanych pierścieni, zaś niepolarną - boczne łańcuchy węglowodorowe. Dzięki obecności żywic możliwe jest powstawanie sterycznych koloidów [25].

Koloidalny układ dyspersyjny tworzony przez asfalteny otoczone żywicami jest zasadniczo niestabilny. Równowaga może być łatwo zakłócona poprzez usunięcie żywic lub węglowodorów aromatycznych albo zwiększenie ilości węglowodorów nasyconych. Na skutek dodania np. n-heptanu równowaga miceli zostaje zaburzona, przez co asfalteny łączą się w coraz większe agregaty. Ostatecznie prowadzi to do ich wytrącenia w postaci szlamu. Możliwość odwrócenia tego procesu zależy od natury asfaltenów i żywic, a także od stopnia zaawansowania wzrostu koloidów [4, 19, 31].

Największe prawdopodobieństwo wytrącania się asfaltenów występuje, gdy ropa jest w maksymalnym stopniu nasycona węglowodorami lekkimi $\left(\mathrm{C}_{1}-\mathrm{C}_{3}\right)$. Są one słabymi rozpuszczalnikami asfaltenów, a więc ich obecność ogranicza rozpuszczalność tych składników. Z tego powodu zjawisko wytrącania asfaltenów może zaistnieć $\mathrm{w}$ trakcie zatłaczania gazu ziemnego do złóż ropy jako medium wspomagającego wydobycie. Gdy ciśnienie ulega obniżeniu, zachodzi desorpcja rozpuszczonych w ropie najlżejszych węglowodorów, co skutkuje polepszeniem rozpuszczalności asfaltenów. Następuje ich stopniowe rozpuszczanie, a w konsekwencji zanik fazy asfaltenowej. Dolna wartość ciśnienia, przy której do tego dochodzi, nazywana jest dolnym ciśnieniem zaniku lub pojawienia się asfaltenów, a więc dolnym ciśnieniem obszaru asfaltenowego (rysunek 6) [30].

Jako że węglowodory parafinowe są słabymi rozpuszczalnikami asfaltenów, ich rozpuszczalność w ropie rośnie wraz ze zwiększaniem ciśnienia. Wzrost tego parametru powyżej

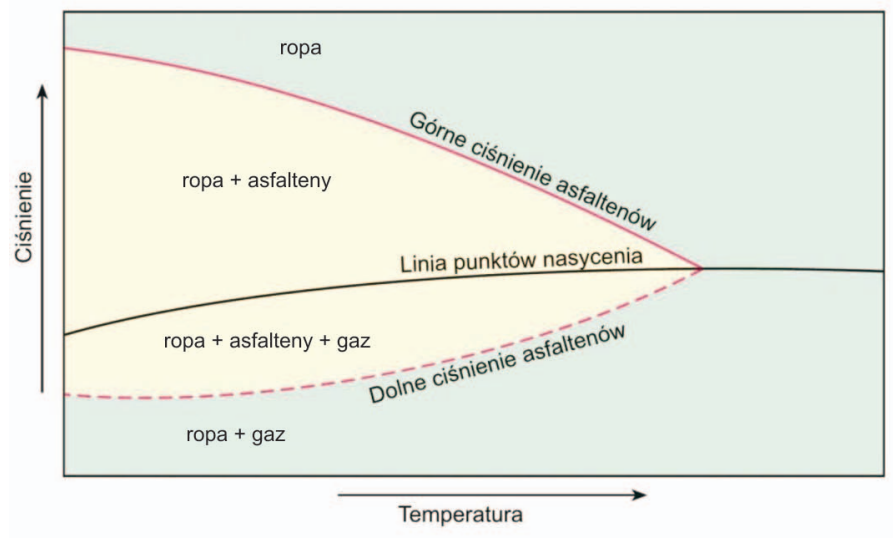

Rys. 6. Przykładowy diagram fazowy ropy tworzącej flokulacje asfaltenowe [30]

wartości punktu nasycenia również sprawia, że faza asfaltenowa ulega stopniowemu rozpuszczaniu. Przy wystarczająco wysokiej wartości ciśnienia, nazywanej górnym ciśnieniem pojawienia się lub zaniku asfaltenów (górnym ciśnieniem asfaltenów), faza asfaltenowa zanika (rysunek 6) [30].

Ze względu na duży rozmiar oraz powinowactwo adsorpcyjne do stałych powierzchni flokulaty asfaltenów mogą tworzyć stabilne, trudne do usunięcia osady [19]. Zatykają one rurociągi i aparaturę procesową, powodując konieczność zwiększenia nakładów energetycznych w celu utrzymania ciągłości przepływu. Przykład zapchania wymiennika ciepła przez osady asfaltenowe podczas tłoczenia pozostałości podestylacyjnej pokazano na rysunku 7.

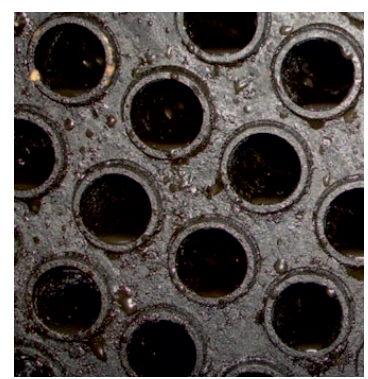

Rys. 7. Wymiennik ciepła zatkany przez wytrącone osady asfaltenów

Często oczyszczanie aparatury za pomocą mycia rozpuszczalnikiem aromatycznym (np. ksylenami) okazuje się niewystarczające i potrzebne jest mechaniczne usuwanie osadów [1]. To kolejna przyczyna strat, ponieważ czyszczony rurociąg lub aparat musi być wyłączony z użytku. Ponadto usunięte osady są traktowane jak odpady i utylizowane, a gdyby udawało się zapobiegać wytrącaniu, cząsteczki je tworzące mogłyby trafiać do ciężkich olejów opałowych albo w procesach destrukcyjnych ulegać częściowej konwersji do wysokomarżowych lżejszych produktów, np. benzyny czy gazu płynnego. To ostatnie nie jest wszakże pozbawione problemów, ponieważ asfalteny są prekursorami koksu dezaktywującego 
katalizatory destrukcyjnych procesów wodorowych. W asfaltenach znajdują się też spore ilości metali, również będących truciznami katalizatorów.
Obecnie najlepszym rozwiązaniem w walce z osadami asfaltenowymi jest zapobieganie ich wytrącaniu, czyli poprawa stabilności fazowej ropy naftowej i produktów jej przerobu.

\section{Ocena stabilności fazowej substancji zawierających asfalteny i jej poprawa za pomocą dodatków dyspergujących}

Mianem stabilności fazowej ropy naftowej określa się jej zdolność do utrzymania asfaltenów w formie zdyspergowanej lub rozpuszczonej w maltenach i do nieulegania flokulacji i wytrącaniu [4]. Miarą stabilności jest punkt flokulacji asfaltenów, oznaczony jako ułamek objętościowy n-alkanu początkujący strącanie osadu asfaltenowego [24].

Początek flokulacji wyznacza się, stosując różne metody badawcze. Należą do nich m.in.: miareczkowanie turbidymetryczne, pomiar zmian mętności promieniowania widzialnego, pomiar intensywności światła odbitego, pomiar zmiany współczynnika refrakcji, pomiar absorpcji światła i fluorescencji, metoda konduktometryczna, pomiar przewodnictwa cieplnego, spektroskopia ultradźwiękowa, pomiar oporu filtracji, zmiany wielkości napięcia międzyfazowego. Do najbardziej rozpowszechnionych sposobów oznaczania punktu flokulacji asfaltenów zalicza się metody optyczne. Wykorzystują one zmiany absorpcji lub rozpraszania światła przez układ koloidalny, wywołane zmianami jego stopnia dyspersji [24].

Jedną z najprostszych i relatywnie tanich metod określania stabilności fazowej jest pomiar zmian mętności w czasie. 10-proc. roztwór ropy lub produktu naftowego w toluenie wprowadza się do czystego n-heptanu. Następnie przy użyciu turbidymetru przez określony czas rejestruje się mętność przygotowanej mieszaniny. Z uzyskanych wyników oblicza się indeks stabilności (ang. stability index, SI), który informuje o wielkości zmian mętności zachodzących podczas pomiaru. Im jest on wyższy, tym zmiany te są większe, a więc stabilność koloidalna badanej próbki mniejsza [18, 32].

Nowe badania poddają w wątpliwość prawidłowość dotychczasowych metod badania stabilności i procesu flokulacji asfaltenów. Zdaniem Vilasa Bôasa Fávero i in. oznaczanie punktu flokulacji jest błędne. Zamiast niego należy badać czas detekcji, tzn. czas, po jakim na skutek dodania określonej porcji n-heptanu pojawiają się agregaty asfaltenów obserwowalne pod mikroskopem (średnica co najmniej 0,5 $\mu \mathrm{m}$ ). O stabilności ropy bądź produktu naftowego mówi położenie i nachylenie prostej będącej zależnością czasu detekcji (w skali logarytmicznej) od ilości dodanego n-heptanu wyrażonej jako procent objętościowy. Im wyżej położona prosta oraz im mniejsze jej nachylenie, tym stabilniejsza substancja zawierająca asfalteny. Dodatkowo istotne jest wagowe oznaczanie ilości asfaltenów wytrącanych przez daną objętość n-heptanu. Inną miarodajną techniką jest również badanie spadku ciśnie- nia, jaki wywołują osady asfaltenowe powstałe przy tłoczeniu przez specjalną kapilarę ropy bądź produktu naftowego wraz z określoną objętością n-heptanu [28].

Poprawę stabilności ropy i produktów naftowych uzyskuje się, stosując odpowiednie dodatki lub komponenty. Powinny one pełnić rolę żywic w stabilnych układach koloidalnych, dlatego pożądane jest, aby charakteryzowały się składem chemicznym i właściwościami zbliżonymi do żywic naftowych, zawierających w swoich cząsteczkach kilka pierścieni aromatycznych (nierzadko $\mathrm{z}$ atomami tlenu, azotu i siarki) oraz boczne łańcuchy węglowodorowe (rysunek 8).

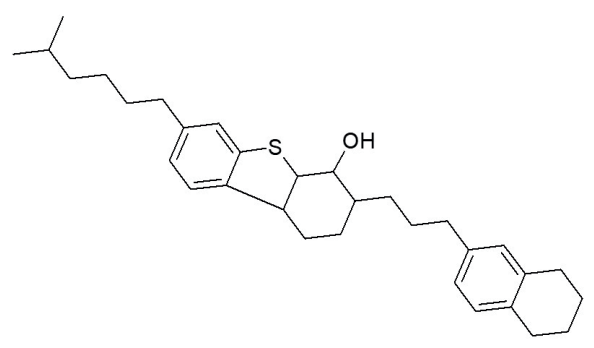

Rys. 8. Przykładowa cząsteczka żywicy naftowej

Porównanie różnych rodzajów dodatków, takich jak węglowodory aromatyczne, donory protonów czy związki heteroorganiczne, pozwala stwierdzić, że największą skuteczność stabilizacji asfaltenów wykazują anionowe związki powierzchniowo czynne (surfaktanty). Efektywność takiego związku jest wyższa niż dodatku niejonowego, co prawdopodobnie wynika z bardzo silnego przyciągania anionu przez polarną powierzchnię asfaltenów posiadającą niewielki ładunek dodatni [23].

Badania Al-Sahhafa i in. [2] wykazały, że surfaktanty będące związkami aromatycznymi z grupami polarnymi oraz długimi łańcuchami alkilowymi są bardzo dobrymi inhibitorami wytrącania asfaltenów. Ich skuteczność była dużo większa niż toluenu, żywic naftowych oraz deasfaltyzatu. Spośród zbadanych surfaktantów, którymi były p-nonylofenol, kwas p-dodecylobenzenosulfonowy oraz p-dodecylorezorcyna, najlepszym inhibitorem okazał się ostatni z wymienionych. Struktury cząsteczek tych związków przedstawiono na rysunku 9.

Mechanizm działania stabilizującego dodatków wyjaśnia się na podstawie modelu micelizacji asfaltenów, tzn. adsorpcji grup polarnych dodatku na polarnych cząsteczkach asfaltenów i orientacji grup niepolarnych w stronę fazy rozpraszającej, czyli maltenów [23]. Dodatki wiążą się polarnymi 
a)<smiles>CCCCc1ccc(O)cc1</smiles>

b)<smiles>CCCCCc1ccc(S(=O)(=O)O)cc1</smiles>

c)

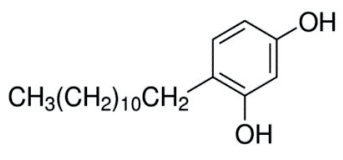

Rys. 9. Wzory półstrukturalne: a) p-nonylofenolu, b) kwasu p-dodecylobenzenosulfonowego, c) p-dodecylorezorcyny

fragmentami z cząsteczkami asfaltenów poprzez oddziaływania kwas-zasada i wiązania wodorowe, stąd zwiększona efektywność dodatków zawierających grupy polarne. Ugrupowania takie jak $-\mathrm{SO}_{3} \mathrm{H}$ oraz $-\mathrm{OH}$ są donorami protonów, które wchodzą $\mathrm{w}$ interakcje $\mathrm{z}$ wiązaniami $\mathrm{C}=\mathrm{C}$ oraz grupami zasadowymi w asfaltenach. W przypadku grupy sulfonowej bardzo prawdopodobna jest jej addycja elektrofilowa do elektronów $\pi$ wiązań nienasyconych. Wadą posiadania przez dyspergator wyżej wymienionych grup jest możliwość ich asocjacji ze sobą, przez co mniejsza liczba cząsteczek asfaltenów może być pokryta przez cząsteczki dodatku i jego skuteczność może być niższa $[9,10]$.

Adsorpcja surfaktantów na powierzchni cząstek asfaltenów zachodzi dwustopniowo. W pierwszym etapie ulegają jej pojedyncze cząsteczki. Gdy ich stężenie na powierzchni dostatecznie wzrośnie, następuje drugi etap, którym jest powstawanie micel surfaktantu na powierzchni cząsteczki. Utworzona warstwa adsorpcyjna stanowi barierę steryczną, zapobiegającą flokulacji. Oprócz przesuwania równowagi roztwór-dyspersja, określonej początkiem flokulacji asfaltenów, dodatki stabilizujące mogą także zmniejszać kinetykę wytrącania osadów [2, 11, 23].

Badania Goual i in. wykazały, że długość łańcucha bocznego dyspergatora nie wpływa na początek flokulacji asfaltenów, ale powoduje zmniejszenie rozmiaru agregatów. Minimalna liczba atomów węgla w łańcuchu powinna wynosić dziewięć (według Changa i Foglera - sześć [9]). Obrazy uzy- skane z użyciem wysokorozdzielczej transmisyjnej mikroskopii elektronowej pokazały, że agregaty asfaltenów powstałe w obecności dodatków miały struktury włókniste, w przeciwieństwie do kulistych flokulatów asfaltenów niedyspergowanych. Za przyczynę uznano tworzenie przez alkilofenole wiązań wodorowych z grupami zasadowymi łańcuchów bocznych asfaltenów [12].

Dzięki adsorpcji na powierzchni asfaltenów oraz utworzeniu przez łańcuchy boczne bariery sterycznej polarne dyspergatory utrudniają agregację asfaltenów. Niestety ich obecność nie zawsze działa pozytywnie. Lin i in. w swojej pracy [17] sprawdzili wpływ dodatków z rodzaju alkilofenoli na ilość osadów asfaltenowych powstających podczas tłoczenia substancji zawierających asfalteny przez porowaty mikrokanał. Okazało się, że w przypadku roztworu asfaltenów w toluenie zmniejszenie osadotwórczości wystąpiło tylko przy zastosowaniu p-dodecylofenolu oraz p-izododecylofenolu. W przypadku p-heksylofenolu oraz p-oktylofenolu efekt był odwrotny.

Oprócz roztworu asfaltenów w toluenie zbadano także skłonność do wytrącania osadów w wysokoparafinowej (69,60\% mas. węglowodorów nasyconych) ropie naftowej. W przypadku obu zastosowanych dodatków, tj. p-oktylofenolu oraz p-dodecylofenolu, zaobserwowano szybszy przyrost ilości osadów w czasie [17]. Prawdopodobnie dodatki zakłóciły równowagę układu żywic i asfaltenów w badanej ropie, same nie wytwarzając wystarczającej bariery sterycznej.

\section{Podsumowanie}

Ze względu na rosnące zapotrzebowanie na benzynę i olej napędowy, czyli tzw. jasne produkty przerobu ropy naftowej, wzrasta zainteresowanie głęboką konwersją rop ciężkich oraz pozostałości podestylacyjnych. Podczas przerabiania ciężkich surowców najważniejszy problem stanowi obecność asfaltenów, która jest głównym powodem powstawania osadów oraz dezaktywacji katalizatorów. Asfalteny i związane przez nie metale osadzają się na powierzchni katalizatorów procesów wodorowych, powodując blokowanie porów. W związku z tym do projektowania coraz lepszych, odpornych na zatrucie katalizatorów niezbędna jest szeroka wiedza o strukturze i właściwościach cząsteczek asfaltenów.

Składy elementarne asfaltenów z różnych surowców nie różnią się znacząco, czego nie można powiedzieć o budowie czą- steczek. W zależności od rodzaju surowca, jego wieku i miejsca pochodzenia struktury asfaltenów bywają bardzo różne, co utrudnia zunifikowany opis zachowania rop naftowych pod kątem wytrącania osadów asfaltenowych. Bezsprzecznie cechą wspólną wszystkich asfaltenów jest wynikająca z polarności skłonność do agregacji, będąca przyczyną wspomnianego tworzenia osadów. Obecność osadów powoduje zwiększenie oporów przepływu w rurociągach, a czasem także ich całkowitą niedrożność. Wiąże się to ze stratami finansowymi koncernów wydobywających oraz przerabiających ropę naftową.

Wobec powyższego niezbędne są ciągłe badania asfaltenów, ich właściwości fizykochemicznych, procesów prowadzących do wytrącania osadów oraz sposobów ograniczania tego zjawiska. 
Prosimy cytować jako: Nafta-Gaz 2018, nr 9, s. 690-697, DOI: 10.18668/NG.2018.09.08

Artykuł przysłany do Redakcji 12.06.2018 r. Zatwierdzony do druku 26.07.2018 r.

\section{Literatura}

[1] Abkarzadeh K., Hammami A., Kharra A., Zhong D., Allenson S., Creek J., Kabir S., Jamaluddin A., Marshall A.G., Rodgers R.P., Mullins O.C., Solbakken T.: Asphaltenes - problematic but rich in potential. Oilfield Review 2007, vol. 19, no. 2, s. 22-43.

[2] Al-Sahhaf T.A., Fahim M.A., Elkilani A.S.: Retardation of asphaltene precipitation by addition of toluene, resins, deasphalted oil and surfactants. Fluid Phase Equilibria 2002, vol. 194, s. 1045-1057. DOI: 10.1016/S0378-3812(01)00702-6.

[3] Altamirano J.J., Flores M.A., Pie O., Panivino N., Arzate C., Kapellman G., Lopez M.T., Spinoza S., Rosales S.: Precipitación de asfaltenos del crudo Maya en un sistema a presión. Revista de la Sociedad Química de México 2004, vol. 48, no. 3, s. $179-188$.

[4] Ancheyta J., Trejo F., Rana M.: Asphaltenes. Chemical transformation during hydroprocessing of heavy oils. CRC Press/ Taylor \& Francis Group, Boca Raton, 2009.

[5] Andrews A.B., Guerra R.E., Mullins O.C., Sen P.N.: Diffusivity of Asphaltene Molecules by Fluorescence Correlation Spectroscopy. Journal of Physical Chemistry A 2006, vol. 110, no. 26, s. 8093-8097. DOI: 10.1021/jp062099n.

[6] Boduszynski M.W.: Asphaltenes in Petroleum Asphalts: Composition and Formation. [W:] Bunger J.W., Li N.C. (eds.): Chemistry of Asphaltenes. American Chemical Society, Washington DC 1981, s. 119-135. DOI: 10.1021/ba-1981-0195.ch007.

[7] Calemma V., Iwanski P., Nali M., Scotti R., Montanari L.: Structural characterization of asphaltenes of different origins. Energy Fuels 1995, vol. 9, no. 2, s. 225-230. DOI: 10.1021/ ef00050a004.

[8] Carbognani L.: Molecular structure of asphaltene proposed for 510 c residue of Venezuelan crude residue. INTEVEP S.A. Tech. Report, 1992.

[9] Chang C.-L., Fogler H.S.: Stabilization of Asphaltenes in Aliphatic Solvents Using Alkylbenzene-Derived Amphiphiles. 1. Effect of the Chemical Structure of Amphiphiles on Asphaltene Stabilization. Langmuir 1994, vol. 10, s. 1749-1757. DOI: 10.1021/la00018a022.

[10] Chang C.-L., Fogler H.S.: Stabilization of Asphaltenes in Aliphatic Solvents Using Alkylbenzene-Derived Amphiphiles. 2. Study of the Asphaltene-Amphiphile Interactions and Structures Using Fourier Transform Infrared Spectroscopy and Small-Angle X-ray Scattering Techniques. Langmuir 1994, vol. 10, s. 1758-1766. DOI: 10.1021/la00018a023.

[11] Da Silva Ramos A.C., Haraguchi L., Notrispe F.R., Loh W., Mohamed R.S.: Interfacial and colloidal behaviour of asphaltenes obtained from Brazilian crude oils. Journal of Petroleum Science \& Engineering 2001, vol. 32, s. 201-216. DOI: 10.1016/ S0920-4105(01)00162-0.

[12] Goual L., Sedghi M., Wang X., Zhu Z.: Asphaltene Aggregation and Impact of Alkylphenols. Langmuir 2014, vol. 30, s. 5394-5403. DOI: 10.1021/la500615k.

[13] Groenzin H., Mullins O.C.: Molecular size and structure of asphaltenes from various sources. Energy Fuels 2000, vol. 14, no. 13, s. 677-684. DOI: 10.1021/ef990225z.

[14] Hiemenz P.C., Rajagopalan R.: Principles of Colloid and Surface Chemistry. Marcel Dekker, New York 1997.

[15] Hortal A.R., Martínez-Haya B., Lobato M.D., Pedrosa J.M., Lago S.: On the Determination of Molecular Weight Distributions of Asphaltenes and Their Aggregates in Laser Desorption
Ionization Experiments. Journal of Mass Spectrometry 2006, vol. 41, no. 7, s. 960-968. DOI: 10.1002/jms.1056.

[16] Kokal S.L., Sayegh S.G.: Asphaltenes: The Cholesterol of Petroleum. Society of Petroleum Engineers: Richardson, TX, USA, 1995. DOI: 10.2118/29787-MS.

[17] Lin Y.-J., He P., Tavakkoli M., Mathew N.T., Yap Y.T., Chai J.C., Goharzadeh A., Vargas F.M., Biswal S.L.: Characterizing Asphaltene Deposition in the Presence of Chemical Dispersants in Porous Media Micromodels. Energy \& Fuels 2017, vol. 31, no. 11, s. 11660-11668. DOI: 10.1021/acs.energyfuels.7b01827.

[18] Lorek A.: Badanie stabilności fazowej produktów naftowych metoda turbidymetryczna. Przemysł Chemiczny 2017, t. 96, nr 4, s. 737-740. DOI: 10.15199/62.2017.4.7.

[19] Mansoori G.A.: Unified perspective on the phase behaviour of petroleum fluids. International Journal of Oil, Gas and Coal Technology 2009, vol. 2, no. 2, s. 141-162. DOI: 10.1504/ IJOGCT.2009.024884.

[20] Merdrignac I., Desmazières B., Terrier P., Delobel A., Laprévote O.: Analysis of Raw and Hydrotreated Asphaltenes Using OffLine and On-Line SEC/MS Coupling. Conference materials, International Conference on Heavy Organics Deposition, Los Cabos, Baja California, Mexico, 14-19 November 2004.

[21] Mullins O.C., Sheu E.Y., Hammami A., Marshall A.G: Asphaltenes, Heavy Oils and Petroleomics. [W:] Freed D.M., Lisitza N.V., Sen P.N., Song Y.Q.: Molecular Composition and Dynamics of Oils from Diffusion Measurements. Springer, New York 2007, s. 279-299. DOI: 10.1007/0-387-68903-6_11.

[22] Mullins O.C., Sheu E.Y., Hammami A., Marshall A.G.: Asphaltenes, Heavy Oils and Petroleomics. [W:] Rodgers R.P. and Marshall A.G.: Petroleomics: Advanced Characterization of Petroleum-Derived Materials by Fourier-Transform Ion Cyclotron Resonance Mass Spectrometry (FT-ICR MS). Springer, New York 2007, s. 63-94. DOI: 10.1007/0-387-68903-6_3.

[23] Paczuski M.: Fizykochemia dyspersji naftowych w optymalizacji technologii rafineryjnej. Oficyna Wydawnicza Politechniki Warszawskiej, Warszawa 2008.

[24] Paczuski M., Lorek A.: Stabilność fazowa ropy naftowej i jej produktów. Nafta-Gaz 2005, nr 11, s. 474-482.

[25] Priyanto S., Mansoori G.A., Suwono A.: Structure and properties of micelles and micelle coacervates of asphaltene macromolecule. Nanotechnology Proceedings of 2001 AIChE Annual Meet.

[26] Qian K., Edwards K.E., Siskin M., Olmstead W.N., Mennito A.S., Dechert G.J., Hoosain N.E.: Desorption and Ionization of Heavy Petroleum Molecules and Measurement of Molecular Weight Distributions. Energy \& Fuels 2007, vol. 21, no. 2, s.1042-1047. DOI: 10.1021/ef060360t.

[27] Suzuki T., Ito Y., Takegami Y., Watanabe Y.: Chemical structure of tar-sand bitumens by $13 C$ and $1 H$ NMR spectroscopy method. Fuel 1982, vol. 61, s. 402-410. DOI: 10.1016/00162361(82)90062-X.

[28] Vilas Bôas Fávero C., Maqbool T., Hoepfner M., Haji-Akbari N., Fogler H.S.: Revisiting the flocculation kinetics of destabilized asphaltenes. Advances in Colloid and Interface Science 2017, vol. 244, s. 267-280. DOI: 10.1016/j.cis.2016.06.013.

[29] Wang S., Liu J., Zhang L., Masliyah J., Xu Zhenghe: Interaction Forces between Asphaltene Surfaces in Organic Solvents. Langmuir 2010, vol. 26, no. 1, s. 183-190. DOI: 10.1021/ la9020004. 
[30] Warnecki M.: Doskonalenie techniki badań warunków flokulacji asfaltenów metoda prześwietlania ropy strumieniem światła podczerwonego. Nafta-Gaz 2011, nr 7, s. 454-462.

[31] Wiehe I.A., Kennedy R.J.: The Oil Compatibility Model and Crude Oil Incompatibility. Energy \& Fuels 2000, vol. 14, no. 1, s. 56-59. DOI: 10.1021/ef990133+.

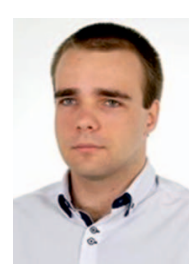

Mgr inż. Przemysław JAROSIŃSKI

Asystent

Politechnika Warszawska, Wydział Budownictwa,

Mechaniki i Petrochemii, Instytut Chemii.

ul. Łukasiewicza 17

09-400 Płock

E-mail:przemyslaw.jarosinski@pw.edu.pl

\section{Akty prawne i normatywne}

[32] Norma ASTM D7061 Standard Test Method for Measuring n-Heptane Induced Phase Separation of Asphaltene - Containing Heavy Fuel Oils as Separability Number by an Optical Scanning Device, 2006.

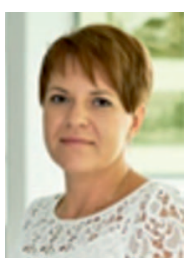

Dr inż. Aneta LOREK

Adiunkt

Politechnika Warszawska, Wydział Budownictwa,

Mechaniki i Petrochemii, Instytut Chemii.

ul. Łukasiewicza 17

09-400 Płock

E-mail: aneta.lorek@pw.edu.pl

\section{OFERTA}

\section{ZAKŁAD OCENY WŁAŚCIWOŚCI EKSPLOATACYJNYCH}

Zakres działania:

- $\quad$ ocena w testach laboratoryjnych właściwości fizykochemicznych oraz użytkowo eksploatacyjnych wg najnowszych procedur badawczych, zarówno europejskich, jak i amerykańskich:

» paliw ciekłych, biopaliw i biokomponentów,

» środków smarowych, w tym: olejów silnikowych, przekładniowych i przemysłowych, zarówno świeżych, jak i przepracowanych;

- $\quad$ pełny zakres usług w zakresie nowoczesnego planowania i monitorowania właściwości olejów smarowych w eksploatacji wraz z oceną zachodzących w nich zmian, doradztwo i ekspertyzy w zakresie użytkowania olejów niewłaściwej jakości lub ich niewłaściwej eksploatacji;

- $\quad$ szeroki zakres ocen stanowiskowych właściwości trybologicznych paliw, środków smarowych oraz cieczy hydraulicznych;

- oceny liczb oktanowych i cetanowych w testach silnikowych wg procedur europejskich i amerykańskich;

- $\quad$ jedyne w kraju oceny właściwości użytkowo-eksploatacyjnych paliw silnikowych wg ogólnoeuropejskich testów silnikowych opracowanych przez CEC i wymaganych między innymi przez Worldwide Fuel Charter;

- oceny kompatybilności dodatków do paliw i olejów smarowych, usługi eksperckie w zakresie problemów związanych z niekompatybilnością wymienionych produktów w eksploatacji;

- $\quad$ oceny właściwości użytkowo-eksploatacyjnych paliw i olejów smarowych w badaniach eksploatacyjnych;

- $\quad$ usługi eksperckie w zakresie wpływu jakości paliw na możliwości powstania dysfunkcji i uszkodzeń silnikowych układów wtrysku paliwa;

- badania procesów regeneracji filtrów cząstek stałych na stanowisku silnikowym, doradztwo w zakresie eksploatacji układów filtracji spalin wyposażonych w filtry cząstek stałych.

Kierownik: dr inż. Zbigniew Stępień

Adres: ul. Łukasiewicza 1, 31-429 Kraków

Telefon: 126177578

Faks: 126177522

E-mail: zbigniew.stepien@inig.pl 